\title{
Regional journals in medicine and public health: A look to the future upon the indexing of the Revista Chilena de Infectología
}

\author{
STEN H. VERMUND, MD, PHD and GUILLERMO ACUÑA, MD
}

Revista Chilena de Infectología has recently been accepted for index listing in the Index Medicus via the MEDLINE data base. This breakthrough prompts reflection on the nature of regionally focused subspecialty journals and what such a listing means for better dissemination of scientific and medical discoveries reported in such journals. There is a conscientious global effort at present to better represent regional journals in indexing systems and to make access easier for persons in less wealthy nations to medical and public health information via the internet. These trends are reviewed and discussed in the context of Chile's national medical and public health literature.

Key words: Medical publishing, Chile, bibliographic indexing, medical journals, public health journals, infectious diseases.

(Versión en idioma español para este artículo en página 16)

Revista Chilena de Infectología (Chilean Journal of Infectious Diseases) is an excellent example of a journal that has both a regional focus and a subspecialty audience. Similar journals are found worldwide, but a majority of them are not currently indexed in any major computerized internet-based data system such as the Index Medicus whose MEDLINE data base of the National Library of Medicine (National Institutes of Health, Bethesda, Maryland, USA) is accessed free of charge via the PubMed on line system (http://www.ncbi.nlm.nih.gov/entrez/query.fcgi). As of mid-2004, PubMed included over 15 million citations for biomedical articles, most dating from 1966 and later, but some of them now dating back to the 1950's. PubMed also includes references from other journals from the life science journals. Of special importance to busy doctors, scientists, and other health workers, PubMed provides links to sites that provide the full text of articles for those pioneering journals that have broadened their reach via the internet, such as the British Medical Journal. An exciting recent innovation is Pub Med Central, launched in 2000.
This initiative is an electronic archive for selected full text journal articles (http://pubmedcentral. nih.gov/). It is hoped that all the major journals will participate eventually. Some journals provide full on-line publication for a time as does the Infectious Diseases Society of America (IDSA); IDSA makes its journals (Journal of Infectious Diseases and Clinical Infectious Diseases) available free, on-line, after one year after their publication. This satisfies the economic imperative of not creating a disincentive to join the IDSA and also satisfies advertisers. (There is also a very low cost membership to IDSA that includes "realtime" journal subscription on line only for health professionals in developing countries.) The World Health Organization (WHO) has been seeking arrangements with cooperating publishers for on line journal access, with developing countries in mind (http://www.who.int/tdr/kh/res_link.html\# journals). Working with WHO to ensure developing country access without compromising their North American or European subscription base is a compromise that many organizations and editors are accepting.

Schools of Public Health and Medicine, University of Alabama at Birmingham, USA (SHV).

Escuela de Medicina, Pontificia Universidad Católica de Chile, Santiago, Chile (GAL). 
Still, hundreds of journals published worldwide have not been included in MEDLINE, reflecting the large pool of publications in medicine and public health today that remain largely unknown to a global audience. Titles and, for most articles, English language abstracts, are easily accessed through the global internet at no charge only in those journals that are indexed; non-indexed journals remain obscure and uninfluential beyond the boundaries of their constituents. Not surprisingly, inclusion in computerized information databases like MEDLINE or EMBASE increases the utility of the scientific, clinical, or public health reports for a wider audience of users. Inpast time, Chilean journals have had considerable success at joining the well established Revista Medica de Chile in becoming indexed (Table 1).

In discussing the utility of regional publications in general and regional subspecialty journals in particular, there are at least three key issues that may be considered:

- What is the scientific niche that is most suitable for regional subspecialty journals and general regional journals in contrast to internationally focused subspecialty journals?

- Are these journals useful as they are currently constituted or should reform be considered?

- How can the global biomedical and public health community better meet its obligations to adequately disseminate important information from regional subspecialty journals?

There are a limited number of pages available in the highest impact general medical journals such as The Lancet, the New England Journal of Medicine, the Journal of the American Medical Association, or the British Medical Journal.
Hence, the vast pool of biomedical and public health literature appears in one type of subspecialty journal or another. There are a number of higher impact (as judged by the "citation index" or how often an article is referenced by another article) specialty journals, typically in journals of major societies with large subscription bases that cover an entire discipline, e.g, internal medicine. Publications in the United States dominate this second rung list of high impact journals (e.g., Annals of Internal Medicine, Pediatrics, and the American Journal of Obstetrics and Gynecology), almost certainly due to the large number of subscribing physicians and medical libraries in North America and the influence of the huge biomedical research budget from the United States Public Health Service, largely from NIH whose fiscal year 2005 budget is likely to be at least $\$ 28.8$ billion. If most of the funding for global biomedical research comes from the NIH and goes to US-based investigators, then it is logical that most journal articles will be published in journals that other funded investigators will read. Of course, there is a large pool of European (nearly all the larger nations), Australian, Canadian, Japanese, and middle-income nation investigators (e.g., Brazil, Chile, Thailand, India, Russia, South Africa) that have their own national publication outlets. There are even nations with lower incomes that have a number of vibrant national journals, such as China, or at least one national journal (many, many nations). Regional journals that cover Europe or Southeast Asia, East Africa, Latin America, or others can provide national relevance but with multiple nations participating. These may focus on the region itself (e.g., East African Medical Journal) or

Table 1. Journals from Chile the have been listed with the National Library of Medicine MEDLINE indexing system before December 2004

\begin{tabular}{ll}
\hline Journal Title & Official Journal Abbreviation \\
\hline Revista Médica de Chile & Rev Méd Chile \\
Boletín Sociedad Chilena de Obstetricia y Ginecología & Bol Soc Chil Obstet Ginecol \\
Boletín Asociación Chilena de Protección de la Familia & Bol Asoc Chil Prot Fam \\
Odontología Chilena & Odontol Chil \\
Revista Chilena de Higiene y Medicina Preventiva & Rev Chil Hig Med Prev \\
Revista Chilena de Historia Natural & Rev Chil Hist Nat \\
Revista Chilena de Historia y Geografía & Rev Chil Hist Geogr \\
Revista Chilena de Nutrición & Rev Chil Nutr \\
Revista Chilena de Obstetricia y Ginecología & Rev Chil Obstet Ginecol \\
Revista Chilena de Odontoestomatología & Rev Chil Odontoestomatol \\
Revista Chilena de Pediatría & Rev Chil Pediatr \\
Revista Chilena de Infectología & Rev Chil Infect \\
\hline
\end{tabular}


may target a specific topic area as well as a specific area (e.g., Southeast Asia Journal of Tropical Medicine and Public Health). One journal, International Health and Tropical Medicine, was created in Europe with an intended global audience, but it subsumed four Europeanbased tropical medicine journals (from Belgium, Britain, Germany, and the Netherlands, with additional participation from Switzerland) that were based in society memberships or were produced from schools of tropical medicine ${ }^{1}$. Hence, a larger readership was secured for an international journal that replaced national journals with smaller readerships ${ }^{1}$.

The scientific niche of a regional journal may be many-fold. First, a journal may link together doctors, nurses, public health professionals, or other scientists who wish to communicate locally relevant research, share regional administrative data, and/or communicate in the national tongue (e.g., Revista Medica de Chile, Puerto Rican Journal of Medical Sciences, Southern Medical Journal (focusing on the southern states in the USA), Zambian Medical Journal, Tidsskrift for Den norske laegeforening (from Norway, in Norwegian, typical of many national journals worldwide), and the Brazilian Journal of Medical and Biological Research). It is easy to see how a journal focused on the national medical interests of doctors in Czech Republic, Chile, Vietnam, or a hundred other countries would be useful, independent of any consideration of global impact. Second, a journal may bind together a subspecialty group in a national or regional context. Revista Chilena de Infectología, the family of journals that are the European Journal of [specialty], the Canadian Journal of Public Health, and many others are examples of this genre. Many represent societies and have base constituencies. Third, a journal may meet a specific language need (this overlaps with the above two niches, of course) such that a Thai, Chinese, or Russian journal might be published for those professionals who are not fluent English speakers. The Boletin Panamericano from the Pan American Health Organization publishes original work or reprinted translations for a Latin American audience that needs Spanish-language material, and is the sister journal to the English language Bulletin of the Pan American Health Organization. There should be no doubt that regional journals fill a valuable niche that less specifically focused journals would not accommodate.

Given the utility of regional journals, what is the best way to use them or to reform them?
First of all, editors should distinguish news articles from biomedical research or clinical papers, insisting on a peer review system for the latter articles. For example, a regional journal might wish to communicate amongst its members and such a communication would need editorial oversight, but would not require peer review in most cases. However, there are no good reasons to forego peer review for any articles that claim to advance science. The authors and editors alone are not objective or expert enough to judge the merit of such work; each has an incentive for publishing. The objective peer reviewer, qualified in the field, is a complement to editorial expertise in making these judgments. A journal that does not conduct peer review will never been taken seriously in the biomedical arena. Second, a journal that seeks to encompass a particular discipline (e.g., internal medicine, surgery, infectious diseases, nephrology, and public health) should seriously consider a regional focus. For example, the Brazilian Journal of Infectious Diseases publishes in English to enable a wider global impact, presumably, and has been included in the Index Medicus. Revista Chilena de Infectología is published in English and Spanish, is provided on a CD-ROM as well, and based on the 2004 decision to include it in the Index Medicus, will similarly reach a global audience. The dilemma of the National Library of Medicine as it copes with a burgeoning global pool of biomedical journals is to include for indexing those journals that meet a global standard of editorial quality, including rigorous peer review. There may come a day that those indexed journals such as the Brazilian Journal of Infectious Diseases and the Revista Chilena de Infectología might merge as a "Latin American Journal of Infectious Diseases," much as the Scandinavian Journal of [subject] series functions or what the International Health and Tropical Medicine journal did in consolidating national journals in Europe ${ }^{1}$. Regional journals may make a larger impact, perhaps, than either the Brazilian or the Chilean journals on their own, but cross-national collaboration in medical publishing introduces language challenges and editorial complications, so this idea awaits a future day. In the internet era, publishing in three languages need not be too costly, because the internet could be used for the other two languages not preferred by the authors; for example, an article written in Spanish could be reviewed and published in Spanish, with Portuguese and English translations on the Internet. Fewer journals would be judged a boon by nearly all overwhelmed scientists and clinicians. But loss of regional 
focus and national specificity would be the negative "trade-off" for this kind of arrangement. Regional consolidation of similar topic journals could achieve goals of language and topic relevance as well as increasing the readership and influence of the journal. Even without consolidation, web sites can be created to enable better access of Latin American literature, as has been done to some extent with the "free medical journals" web site (http://www.freemedical journals.com/). A side benefit might be that regional collaborations would be facilitated by the shared editorial and publishing responsibilities.

The global health community does not benefit equally from articles published in various journals. For example, if a health professional is based at a hospital, those journals available by personal or institutional subscription are all that are available; those available on the internet are most immediately useful when internet is readily available. Many more sophisticated libraries can send requests for interlibrary loans for articles that may not be in immediately available journals. Some, but not all, authors will provide reprints upon receipt of a postcard request. Least useful are those journals that are hard to access and whose articles are not available in an on-line service. And if the journal is not indexed, how does someone who does not have access to the journal know that the article of interest even exists? It is our view that regional journals have a vital role to play both regionally and internationally but that indexing be sought after once the journal meets the rigorous peer reviewing standards of the $\mathrm{NLM}^{2}$. An article on Streptococcus agalactiae (Group B streptococcal) disease in Chilean newborns may seem to be of regional interest until a Scandinavian investigator sees a remarkable similarity or difference between her/his own data and that of the Chilean study; a new risk factor is suggested and a new finding is facilitated. This will not occur if the Chilean article is unknown to the Scandinavian researcher. The reverse will not occur since all Scandinavian regional journals are included in the Index Medicus. Hence, Chileans benefit from the global literature but the international community benefits far less from the Chilean literature, a deficit corrected for the Revista Chilena de Infectología thanks to the recent National Library of Medicine decision to index the journal. The NLM has still not managed to index all the articles in relatively small medical journal pool prior to 1966, making older articles similarly elusive, depending on oldfashioned hand searches through Index Medicus annual summary indices. An Elsevier private indexing service (EMBASE; http://www.embase. $\mathrm{com} /$ ) may expand its European-focused service to include other global journals. The preferred option of expanding the Index Medicus data base is happening now with an explicit effort by the NLM to index more journals through the OLDMEDLINE database that is accessed easily through the NLM Gateway as well as to be more inclusive in journals indexed ${ }^{3,4}$. The global medical community should attend to the matter -WHO in particular- by continuing to providing advocacy for on-line access, particularly for resource-limited countries. NLM continues to take responsibility for ongoing maintenance of the databases, a huge boon to the global medical, nursing, public health, and biology communities.

There are many articles that we have published over the years in regional journals with the specific goal of reaching a regional audience. Examples include those that published in journals that focus on a particular part of one large country such as the USA ${ }^{5-7}$, those that have a specific national focus such as Chile or Japan ${ }^{8-19}$, or those that focus on a particular global region such as southeast Asia or Latin America ${ }^{20-25}$. It is now gratifying that the impact of the Revista Chilena de Infectología publications will be greater in the future than for non-indexed articles. The global "win-win" would be to regionalize subspecialty journals to include countries of like interest and geographic coherence to increase the legitimacy for indexing. Once indexed and once crossing national borders, the journal's impact will rise with its broadened readership, especially if full articles can be accessed over the Internet. We are convinced that the advent of a Spanish language infectious disease journal listed on the Index Medicus, Med Line, and Pub Med, with additional access to the articles over the internet will improve information access for many physicians, nurses, and scientists in Latin America, the Caribbean, Spain, and even in other countries such as Equatorial Guinea and the USA where many physicians have been trained in Spanish or have Spanish as their mother tongue. The recent index inclusion of the Revista Chilena de Infectología will go a long way towards increasing global access to its valuable contents.

Acknowledgment: We would like to thank the Infectious Diseases Society of America for its written support in securing MEDLINE indexing status for the journal and for its excellent web links page (http://www.idsociety.org/Template. $\mathrm{cfm}$ ?Section=Related_Links\&Template $=/$ Content Management/ContentDisplay.cfm\&ContentID $=$ 7031). 


\section{References}

1.- Bradley D. Change and continuity in tropical medical science and international health. Trop Med Int Health 1996; 1: 1-2.

2.- Lee D H. Taehan Kan Hakhoe Chi (The Korean Journal of Hepatology) and Index Medicus (Medline/ PubMed). Taehan Kan Hakhoe Chi 2003; 9 (1): 3541. (Authors' Note: Article is in Korean, but do not hesitate to look it up on the PubMed).

3.- Tomasulo P. The NLM Gateway: something old, something new. Med Ref Serv Q 2004; 23: 41-9.

4.- Lacroix E M, Mehnert R. The US National Library of Medicine in the 21st century: expanding collections, nontraditional formats, new audiences. Health Info Libr J 2002; 19: 126-32.

5.- Holmes R, Fawal H, Moon T D, Cheeks J, Coleman J, Woernle C, Vermund S H. Acquired immunodeficiency syndrome in Alabama: Special concerns for AfricanAmerican women. South Med J 1997; 90: 697-701.

6.- Beltrami J F, Vermund S H, Fawal H J, Moon T D, Von Bargen J C, Holmberg S D. HIV/AIDS in nonurban Alabama: Risk activities and access to services among HIV-infected persons in nonurban Alabama. South Med J 1999; 92: 677-83.

7.- DiClemente R J, Funkhouser E, Wingood G, Fawal H, Holmberg D S, Vermund S H. Protease inhibitor combination therapy and decreased condom use among gay men. South Med J 2002; 95: 421-5.

8.- Wolff M, Fich F, Acuña G, Vial P, Wu E, Ripoll E, et al. Antiretroviral therapy. Announcement of the Advisory Committee of the Chilean Society of Infectology on AIDS. Rev Méd Chile 1998; 126: 577-81.

9.- Vial P A, Vial C, Abarca K, Noriega M, Jiménez G, Labarca J, et al. Resistance of human immunodeficiency virus (HIV) to zidovudine. Genotypic analysis in strains isolated from Chilean patients. Rev Méd Chile 1998; 126:17-26.

10.- Vial P A, Ferreccio C, Abarca K, Ortiz E, Noriega M, Pérez $C$, et al. Natural history of human immunodeficiency virus infection in a cohort of Chilean patients. Rev Méd Chile 1996; 124: 525-35.

11.- Pérez C, Sirham M, Labarca J, Grebe G, Lira P, Oliva J, et al. Imipenem/cilastatin versus ceftazidime-amikacin in the treatment of febrile neutropenic patients. Rev Méd Chile 1995; 123: 312-20.

12.- Pérez C, Almendarez C, Oddo D, Sirhan M, Labarca J, Acuña G, et al. Pneumonia caused by Pneumocystis carinii in immunodepressed patients: clinical picture, treatment, and prognosis. Rev Méd Chile 1994; 122: 154-8.
13.- Pérez C, Pérez J, Oddo D, Labarca J, Guzmán S, Acuña $G$, et al. Disseminated histoplasmosis in a patient with acquired immunodeficiency syndrome. Rev Méd Chile 1993; 121: 65-9.

14.- Labarca J, Tagle R, Acuña G, Oddo D, Pérez C, Guzmán S. Acalculous acute cholecystitis caused by Cryptosporidium in a patient with AIDS. Rev Méd Chile 1992; 120: 789-93.

15.- Labarca J, Acuña G, Saavedra H, Oddo D, Sepúlveda $\mathrm{C}$, Ballesteros J, et al. Chagas disease with the acquired immunodeficiency syndrome. Clinical cases. Rev Méd Chile 1992; 120: 174-9.

16.- Torrealba G, Acuña G, Tagle P, Tapia J, Huete I. The value of cerebral biopsy in patients with AIDS and extensive cerebral lesions. Rev Méd Chile 1990; 118: 1367-71.

17.- Lobos T, Acuña G, Espinoza R, León E. Cryptococcosis in acquired immunodeficiency syndrome. Rev Méd Chile 1990; 118: 296-9.

18.- Oddo D, Lobos T, Riquelme R, Thompson L, Acuña G. Zygomycosis: anatomoclinical and mycological study of 17 cases. Rev Méd Chile 1987; 115: 314-8.

19.- Figueroa F, Palacios A, Rivero S, Oddo D, Roa I, Honeyman J, et al. Chronic diarrhea due to Isospora belli and Kaposi's sarcoma in a male homosexual. Report of the 1st case of acquired immunodeficiency syndrome in Chile. Rev Méd Chile 1985; 113: 772-9.

20.- Garris I, Rodríguez E M, de Moya E A, Guerrero E, Pea C, Puello E, et al. El predomino heterosexual del SIDA en la Republica Dominicana. Bol Oficina Sanit Panam 1993; 115: 111-7.

21.- Sankaranarayanan S, Naik E, Reddy P S N, Ganesh K, Gandewar K, Singh K P, et al. Impact of school-based HIV and AIDS education for adolescents in Bombay, India. SE Asian J Trop Med Public Health 1997; 27 : 692-5.

22.- Damiba A, Vermund S H, Kelley K F. Gonorrhea, syphilis, and trichomoniasis among prostitutes in Burkina Faso. E Afr Med J 1990; 67; 473-7.

23.- Islam M M, Karim E, Mian M A, Kristensen S, Chowdhury M R, Vermund S H. An update on the prevelance of HIV/AIDS in Bangladesh. SE Asian J Trop Med Public Health 1999: 30: 246-50.

24.- Pasha O, Fikree F F, Vermund S. Determinants of unmet need for family planning in squatter settlements in Karachi, Pakistan. Asia Pac Popul J 2001; 16: 93108.

25.- Oddo D, Acuña G. Opportunistic infections in Chilean autopsy cases, 1960-1986. Bull Pan Am Health Organ 1988; 22: 17-26.

Correspondencia a:

Sten Vermund

sten@uab.edu

Guillermo Acuña L.

gacuna@netline.cl 


\title{
Revistas regionales de medicina y salud pública: Una mirada al futuro a propósito de la indización de Revista Chilena de Infectología
}

\author{
STEN H, VERMUND, PHD y GUILLERMO ACUÑA L., FACP
}

Palabras claves: publicaciones médicas, Chile, indización bibliográfica, revistas médicas, revistas de salud pública, enfermedades infecciosas.

(Versión en idioma inglés para este artículo en la página 10)

Revista Chilena de Infectología (Chilean Journal of Infectious Diseases) es un excelente ejemplo de una revista que tiene una audiencia regional y de sub-especialidad. Revistas similares pueden encontrarse en todo el mundo, pero la mayoría de ellas no están indizadas en la actualidad en algún sistema importante de datos computarizados basados en la Internet como es Index Medicus cuya base de datos MEDLINE, de la Biblioteca Nacional de Medicina (National Library of Medicine - NLM) perteneciente al Instituto Nacional de Salud (National Institute of Health-NIH), Bethesda, Maryland, EUA, puede ser accedida gratuitamente en línea vía PubMed. (http://www.ncbi.nlm.nih.gov/entrez/query.fcg).

Desde mediados del 2004, PubMed incluye más de 15 millones de publicaciones de artículos bio-médicos, la mayoría aparecidos después de 1966, aunque hay algunos que incluyen publicaciones desde los años 1950. PubMed también incluye referencias de revistas de ciencias de la salud.

Para médicos muy ocupados, es especialmente importante que PubMed incorpore links a sitios que proveen de artículos con texto completo de aquellas revistas pioneras que han decidido aumentar su divulgación vía Internet, como es el British Medical Journal. Una innovación reciente muy interesante es Pub Med Central, lanzada el año 2000. Esta iniciativa es un archivo electróni- co para revistas seleccionadas en texto completo (http://pubmedcentral.nih.gov). Se espera que las más importantes revistas eventualmente participen de esta iniciativa.

Algunas revistas proveen de versiones en línea a texto completo después de un tiempo, como lo hace las revistas de la Sociedad Americana de Infectología (IDSA); IDSA ofrece sus revistas (Journal of Infectious Diseases y Clinical Infectious Diseases) libres de cargo, en línea, después de un año de publicación. Esto satisface las necesidades de no crear un desincentivo para incorporarse a IDSA y cumplir con los avisadores. (Además hay una membresía a IDSA de muy bajo costo que incluye una suscripción a las revistas en su formato electrónico, y que está disponible para profesionales de la salud en países en desarrollo).

La organización mundial de la salud (OMS) ha estado procurando arreglos con editoriales para el acceso en línea a las revistas, pensando en los países en desarrollo (http://www.who.int/tdr/kh/ res_link.html\#journals). El trabajar con la OMS para asegurar el acceso en países en desarrollo, sin comprometer las suscripciones en Norte América y Europa, es un compromiso que muchas editoriales están dispuestas a hacer.

Aun así, cientos de publicaciones a nivel mundial no han sido incluidas en MEDLINE, reflejando el gran pool de publicaciones en medicina y

Escuela de Medicina y Salud Pública, Universidad de Alabama en Birmingham, E.U.A. (SHV).

Escuela de Medicina, Pontificia Universidad Católica de Chile, Santiago, Chile (GAL).

Recibido: 10 diciembre 2004

Aceptado: 30 diciembre 2004 
salud pública que permanecen desconocidas a la audiencia global. Los títulos, y para la mayoría de los artículos, resúmenes en inglés, son fácilmente accesibles a través de la red de Internet, sin costo, solamente en aquellas revistas que han sido indizadas; las revistas no indizadas se mantienen en la oscuridad y sin influencia más allá de su propia circulación.

No es de sorprender entonces que la inclusión en las bases de datos como MEDLINE o EMBASE, aumente la utilidad de los reportes científicos, clínicos o de Salud Pública para una audiencia mayor y más amplia. En el pasado varias revistas Chilenas han tenido éxito en unirse a la bien establecida Revista Médica de Chile, al ser indizadas (Tabla 1).

Al discutir acerca de la utilidad de las publicaciones regionales en general, y en aquellas de sub-especialidad regional en particular, hay al menos tres puntos claves que deben considerarse:

- ¿Cuál es el nicho científico más adecuado para las revistas regionales de subespecialidad y revistas regionales generales, en contraste con las revistas de foco internacional de dichas especialidades?

- ¿Son estas revistas útiles tal como están o se debe considerar modificaciones?

- ¿Cómo puede la comunidad biomédica y de salud pública global cumplir mejor sus obligaciones para diseminar adecuadamente la importante información desde las revistas regionales de subespecialidad?

Hay un número limitado de páginas disponibles en las revistas de mayor impacto de medicina general, tales como The Lancet, New England Journal of Medicine, JAMA o British Journal of Medicine. Sin embargo, la mayor parte de la información biomédica y de salud pública apare- ce en revistas de subespecialidad. Hay un importante número de revistas de subespecialidad con alto impacto (según el criterio del "índice de citaciones" o cuán frecuentemente un artículo es citado por otro). Estas son revistas de grandes sociedades científicas, con gran número de suscriptores, que cubren toda la disciplina, p. ej.: Medicina Interna. En Estados Unidos de América (E.U.A.) estas publicaciones dominan esta segunda banda de revistas de alto impacto (p.ej: Annals of Internal Medicine, Pediatrics, y American Journal of Obstetrics and Gynecology), seguramente por el alto número de suscriptores y de bibliotecas en Norte América y la influencia del gran presupuesto de investigación del Servicio de Salud Pública de Estados Unidos, principalmente del NIH, cuyo presupuesto para el año fiscal 2005 probablemente será de al menos 28.800 millones de dólares. Si la mayor parte de los fondos para investigación biomédica proviene del $\mathrm{NIH}$ y va a investigadores que trabajan en E.U.A., entonces es lógico que la mayoría de los artículos sean publicados en revistas que otros investigadores con el mismo tipo de fondos lean.

Por supuesto hay un gran pool de revistas europeas (en todos los grandes países), australianas, canadienses, japonesas y naciones con ingresos medianos (p. ej.: Brasil, Chile, Tailandia, India, Rusia, Sudáfrica) que tienen sus propias publicaciones. Hay incluso naciones con ingresos bajos que tienen una cantidad de revistas nacionales vibrantes, como China, o al menos una revista nacional (muchas naciones).

Revistas regionales que cubren Europa o el Sudeste Asiático, África del Este, Latino América u otras, pueden proporcionar una importancia nacional pero con muchos países participando. Pueden enfocar a la región misma, (p.ej.: East

Tabla 1. Revistas periódicas chilenas que han sido indizadas por National Library of Medicine MEDLINE antes de diciembre de 2004

\begin{tabular}{ll}
\hline Título de la Revista & Abreviación Oficial \\
\hline Revista Médica de Chile & Rev Méd Chile \\
Boletín Sociedad Chilena de Obstetricia y Ginecología & Bol Soc Chil Obstet Ginecol \\
Boletín Asociación Chilena de Protección de la Familia & Bol Asoc Chil Prot Fam \\
Odontología Chilena & Odontol Chil \\
Revista Chilena de Higiene y Medicina Preventiva & Rev Chil Hig Med Prev \\
Revista Chilena de Historia Natural & Rev Chil Hist Nat \\
Revista Chilena de Historia y Geografía & Rev Chil Hist Geogr \\
Revista Chilena de Nutrición & Rev Chil Nutr \\
Revista Chilena de Obstetricia y Ginecología & Rev Chil Obstet Ginecol \\
Revista Chilena de Odontoestomatología & Rev Chil Odontoestomatol \\
Revista Chilena de Pediatría & Rev Chil Pediatr \\
Revista Chilena de Infectología & Rev Chil Infect \\
\hline
\end{tabular}


África Medical Journal) o enfocar tanto un tema específico como a una región (p.ej.: Southeast Asia Journal of Tropical Medicine and Public Health). Una revista, Internacional Health and Tropical Medicine, fue creada en Europa con la idea de una audiencia global; reemplazó a cuatro revistas europeas de medicina tropical (de Bélgica, Gran Bretaña, Alemania y Países Bajos, con participación adicional de Suiza) que estaban basadas en la membresía de sociedades locales o eran producidas por escuelas de medicina tropi$\mathrm{cal}^{1}$. Así se aseguró un gran número de lectores para una revista que sustituyó revistas nacionales con un pequeño número de lectores.

El nicho científico de una revista regional puede tener varios centros:

- Primero una revista puede conectar a médicos, enfermeras, salubristas, u otros profesionales que quieran comunicar sus experiencias relevantes para la región, compartir datos administrativos, y/o comunicarse en su lengua nativa (p.ej.: Revista Médica de Chile, Puerto Rican Journal of Medical Sciences, Southern Medical Journal [enfocándose en el área de los estados del sur de E.U.A.], Zambian Medical Journal, Tidsskrift for Den norske laegeforening [de Noruega, en noruego, típica de muchas revistas nacionales alrededor del mundo], y Brazilian Journal of Medical and Biological Research). Es fácil ver como una revista enfocada en los intereses médicos nacionales de doctores en la República Checa, Chile, Vietnam y cientos de otros países son útiles, independiente de toda consideración de impacto global.

- Segundo, una revista puede unir a un grupo de subespecialidad en un contexto regional o nacional. Revista Chilena de Infectología es de la familia de las revistas que son European Journal of (especialidad), Canadian Journal of Public Health y muchas otras de este género. Muchas representan sociedades y tienen sus propios miembros / lectores.

- Tercero, una revista puede cubrir la necesidad de un idioma (esto se sobrepone con los dos nichos anteriores), como Thai, Chino, o Ruso y son publicadas para aquellos profesionales que no dominan el inglés. Boletín Panamericano de la Organización Panamericana de la Salud, publica trabajos originales o reproducciones traducidas para la audiencia latinoamericana quienes necesitan material en español, y su revista hermana lo hace en inglés, Bulletin of the Pan American Health Organization. No debiera haber ninguna duda que las revistas regionales llenan un espacio valioso que otras revistas menos dirigidas no pueden acomodar.

Dado la utilidad de las revistas regionales, ¿cuál es la mejor forma de usarlas o transformarlas? Primero los editores deben distinguir entre artículos originales de investigación biomédica o clínica, insistiendo en una revisión por pares de estos artículos. Por ejemplo una revista regional pudiera querer hacer un comunicado a sus miembros y esa comunicación debiera tener una revisión editorial pero no requiere una revisión por pares. Sin embargo, no puede dejar de hacer revisiones por pares de artículos que comunican datos originales. Los autores o editores no son suficientemente expertos para juzgar los méritos de dicho trabajo; cada cual tiene sus propios incentivos para ser publicados. El revisor calificado es un complemento a la pericia editorial para hacer estos juicios. Una revista que no haga revisión por pares, nunca será tomada en cuenta seriamente en la arena biomédica.

Segundo, una revista que pretenda cubrir una disciplina en particular (pej.: Medicina Interna, Cirugía, Infectología, Nefrología y Salud Pública) debe considerar seriamente un foco regional. Por ejemplo Brazilian Journal of Infectious Diseases se publica en inglés para permitir un impacto global más amplio y ha sido incorporada al Index Medicus. Revista Chilena de Infectología es publicada en inglés y español, tiene un CDROM, y dado la decisión de incluirla en el Index Medicus, también tendrá una difusión global similar.

El dilema de la NLM al enfrentarse a una demanda masiva de publicaciones, es incluir para indización de aquellas que cumplan con los estándares globales de publicación, incluyendo una rigurosa revisión por pares. Puede llegar un día en aquellas revistas indizadas, como Brazilian Journal of Infectious Diseases y Revista Chilena de Infectología, puedan fusionarse como una Revista Latino Americana de Infectología, al estilo de la serie de Scandinavian Journal (especialidad) o como Internacional Health and Tropical Medicine hizo para consolidar revistas nacionales en Europa.

Las revistas regionales pueden tener probablemente, un impacto global mayor que la revista brasilera o chilena por separado, pero la colaboración transnacional en publicación médica introduce retos en el idioma y complicaciones editoriales, de modo que esta idea continúa esperando para el futuro.

En la era de Internet, publicar en tres idiomas no necesita ser muy costoso, ya que Internet puede ser usada para los otros dos idiomas no 
elegidos como preferente por el autor; por ejemplo, un artículo en español puede ser revisado y publicado en español, con traducciones en portugués e inglés en Internet.

Pocas revistas serán juzgadas como beneficiosas por casi todos los sobrecargados científicos y clínicos. Pero la pérdida del foco regional y nacional sería específicamente una pérdida para este tipo de arreglos. La consolidación regional de revistas del mismo tópico puede obtener metas de lenguaje y de temas además de un incremento en el número de sus lectores y por lo tanto, de influencia de la revista.

Incluso sin consolidación, se pueden crear sitios web para permitir el mejor acceso a la literatura latinoamericana, como ha sido conseguido en parte con la página de "free medical journals" (http://freemedicaljournals.com/). Un beneficio adicional puede ser que la colaboración regional puede ser facilitada al compartir responsabilidades editoriales y de publicación.

La comunidad de salud global no se beneficia en forma igualitaria de artículos publicados en diversas revistas. Por ejemplo, si un profesional de la salud que trabaja en un hospital tiene a su disposición sólo las revistas que su institución incorpora en su biblioteca; los publicados en Internet podrá usarlos sólo si tiene acceso a ese servicio. Muchas bibliotecas más sofisticadas pueden solicitar artículos de otras revistas mediante préstamos de otras bibliotecas. Algunos autores, pero no todos, enviarán separatas si le son solicitadas por tarjeta postal. Menos útiles son aquellas revistas difíciles de obtener y que no tienen acceso en un servicio en línea. Y si la revista no está indizada, ¿cómo puede una persona que no tiene acceso a la revista siquiera sospechar que el artículo existe? Nosotros pensamos que las revistas regionales cumplen un papel muy importante tanto en la región como en forma internacional, pero que deben buscar la indización cumpliendo los requisitos de revisión por pares de la $\mathrm{NLM}^{2}$. Un artículo de enfermedad por Streptococcus agalactiae en recién nacidos chilenos puede considerarse de interés regional, hasta que un investigador escandinavo observa una interesante coincidencia o diferencia entre sus propios datos con los del estudio chileno; se plantea la posibilidad de un nuevo factor de riesgo que puede ser de gran interés. Esto no ocurriría si el artículo chileno no fuera conocido por el investigador escandinavo. Lo inverso no ocurriría dado que todas las revistas escandinavas están incluidas en Index Medicus. De esta manera los chilenos se benefician de la literatura global pero la comunidad internacional se beneficia mu- cho menos de las publicaciones chilenas, un déficit corregido a la incorporación reciente de Revista Chilena de Infectología a Index Medicus. La NLM todavía no ha conseguido indizar todos los artículos aparecidos en revistas médicas relativamente pequeñas ante de 1966, permitiendo que los artículos más antiguos sean también bastante elusivos y haciéndolos dependientes del antiguo método manual de revisar el índice anual de Index Medicus. Un servicio privado de indización de Elsevier (EMBASE: http://www. embase.com/) puede expandir el servicio focalizado a literatura europea, y a otras revistas globales.

La opción preferida, de expandir la base de datos de Index Medicus está ocurriendo ahora con el esfuerzo explícito de parte de la NLM para indizar más revistas a través de la base de datos OLDMEDLINE que es accesible fácilmente por la NLM Gateway e incluye más revistas ${ }^{3,4}$.

La comunidad médica global debe estar atenta a la materia- la OMS en particular- para continuar abogando por un acceso libre en línea, especialmente para países de escasos recursos. La NLM continúa siendo responsable de la mantención de la base de datos, una gran contribución a las comunidades globales de medicina, enfermería, salud pública y biología.

Hay muchos artículos publicados por nosotros en el transcurso de años en revistas regionales con el propósito de llegar a una audiencia de la región. Algunos ejemplos incluyen aquellos publicados en revistas que se focalizan en un lugar particular de un gran país como E.U.A. ${ }^{5-7}$, aquellos con focos nacionales específicos como Chile o Japón ${ }^{8-19}$, o aquellos que se enfocan en una zona más amplia como Asia o América Latina ${ }^{20-25}$. Es gratificante saber ahora que el impacto de Revista Chilena de Infectología será mayor en el futuro que hasta ahora, antes de su indización.

La ganancia global total sería regionalizar revistas de sub-especialidad para incluir países de intereses comunes y coherencia geográfica para aumentar la legitimación de la indización. Una vez indizado y al traspasar fronteras la revista aumentará su impacto al aumentar sus lectores, especialmente si los artículos se pueden encontrar en texto completo en Internet.

Estamos convencidos que la incorporación de una revista de Infectología en español a Index Medicus, MEDLINE y Pub Med, vía Internet, mejorará el acceso de información para muchos médicos, enfermeras y científicos de Latinoamérica, el Caribe y España e incluso a otros países como Guinea Ecuatorial y los E.U.A. donde muchos médicos han sido entrenados en es- 
pañol o tienen al español como su lengua nativa. La reciente inclusión en el Index de Revista Chilena de Infectología la llevará a un incremento en el acceso de su interesante material.

\section{Resumen}

Revista Chilena de Infectología ha sido aceptada recientemente para ser listada en Index Medicus vía la base de datos de MEDLINE. Esta novedad nos hace reflexionar sobre las revistas de sub-especialidad regionales y qué significa esta incorporación para una mejor diseminación de los descubrimientos científicos y médicos que son reportados en dichas revistas. Actualmente hay un esfuerzo global consciente para representar mejor las revistas regionales en el sistema de indización y para hacer más fácil para personas en naciones de menores recursos acceder a la información médica y de salud pública vía Internet. Estas tendencias son revisadas y discutidas en el contexto de la literatura médica y de la salud pública chilena.

Agradecimientos: a la Sociedad Americana de Infectología (IDSA) por su apoyo por escrito a nuestra postulación frente a la Nacional Library of Medicine, lo que nos ha permitido ingresar a Index Medicus/MEDLINE, y a su excelente link con nuestra página Web (http:/www.idsociety.org/Template. $\mathrm{cfm}$ ?Section $=$ related_Links $\&$ Tempate $=$ Content ManagementContentDisplay.cfm\&ContentID=7031).

\section{Bibliografía}

1.- Bradley D. Change and continuity in tropical medical science and international health. Trop Med Int Health 1996; 1: 1-2.

2.- Lee D H. Taehan Kan Hakhoe Chi (The Korean Journal of Hepatology) and Index Medicus (Medline/ PubMed). Taehan Kan Hakhoe Chi 2003; 9 (1): 3541. (Authors' Note: Article is in Korean, but do not hesitate to look it up on the PubMed).

3.- Tomasulo P. The NLM Gateway: something old, something new. Med Ref Serv Q 2004; 23: 41-9.

4.- Lacroix E M, Mehnert R. The US National Library of Medicine in the 21st century: expanding collections, nontraditional formats, new audiences. Health Info Libr J 2002; 19: 126-32.

5.- Holmes R, Fawal H, Moon T D, Cheeks J, Coleman J, Woernle C, Vermund S H. Acquired immunodeficiency syndrome in Alabama: Special concerns for AfricanAmerican women. South Med J 1997; 90: 697-701.

6.- Beltrami J F, Vermund S H, Fawal H J, Moon T D, Von Bargen J C, Holmberg S D. HIV/AIDS in nonurban Alabama: Risk activities and access to services among HIV-infected persons in nonurban Alabama. South Med J 1999; 92: 677-83.

7.- DiClemente R J, Funkhouser E, Wingood G, Fawal H, Holmberg D S, Vermund S H. Protease inhibitor combination therapy and decreased condom use among gay men. South Med J 2002; 95: 421-5.

8.- Wolff M, Fich F, Acuña G, Vial P, Wu E, Ripoll E, et al. Antiretroviral therapy. Announcement of the Advisory Committee of the Chilean Society of Infectology on AIDS. Rev Méd Chile 1998; 126: 577-81.

9.- Vial P A, Vial C, Abarca K, Noriega M, Jiménez G,
Labarca J, et al. Resistance of human immunodeficiency virus (HIV) to zidovudine. Genotypic analysis in strains isolated from Chilean patients. Rev Méd Chile 1998; 126:17-26.

10.- Vial P A, Ferreccio C, Abarca K, Ortiz E, Noriega M, Pérez $C$, et al. Natural history of human immunodeficiency virus infection in a cohort of Chilean patients. Rev Méd Chile 1996; 124: 525-35.

11.- Pérez C, Sirham M, Labarca J, Grebe G, Lira P, Oliva J, et al. Imipenem/cilastatin versus ceftazidime-amikacin in the treatment of febrile neutropenic patients. Rev Méd Chile 1995; 123: 312-20.

12.- Pérez C, Almendarez C, Oddo D, Sirhan M, Labarca J, Acuña G, et al. Pneumonia caused by Pneumocystis carinii in immunodepressed patients: clinical picture, treatment, and prognosis. Rev Méd Chile 1994; 122: 154-8.

13.- Pérez C, Pérez J, Oddo D, Labarca J, Guzmán S, Acuña $G$, et al. Disseminated histoplasmosis in a patient with acquired immunodeficiency syndrome. Rev Méd Chile 1993; 121: 65-9.

14.- Labarca J, Tagle R, Acuña G, Oddo D, Pérez C, Guzmán S. Acalculous acute cholecystitis caused by Cryptosporidium in a patient with AIDS. Rev Méd Chile 1992; 120: 789-93.

15.- Labarca J, Acuña G, Saavedra H, Oddo D, Sepúlveda C, Ballesteros J, et al. Chagas disease with the acquired immunodeficiency syndrome. Clinical cases. Rev Méd Chile 1992; 120: 174-9.

16.- Torrealba G, Acuña G, Tagle P, Tapia J, Huete I. The value of cerebral biopsy in patients with AIDS and extensive cerebral lesions. Rev Méd Chile 1990; 118: 1367-71.

17.- Lobos T, Acuña G, Espinoza R, León E. Cryptococcosis in acquired immunodeficiency syndrome. Rev Méd Chile 1990; 118: 296-9.

18.- Oddo D, Lobos T, Riquelme R, Thompson L, Acuña G. Zygomycosis: anatomoclinical and mycological study of 17 cases. Rev Méd Chile 1987; 115: 314-8.

19.- Figueroa F, Palacios A, Rivero S, Oddo D, Roa I, Honeyman J, et al. Chronic diarrhea due to Isospora belli and Kaposi's sarcoma in a male homosexual. Report of the 1st case of acquired immunodeficiency syndrome in Chile. Rev Méd Chile 1985; 113: 772-9.

20.- Garris I, Rodríguez E M, de Moya E A, Guerrero E, Pea C, Puello E, et al. El predomino heterosexual del SIDA en la Republica Dominicana. Bol Oficina Sanit Panam 1993; 115: 111-7.

21.- Sankaranarayanan S, Naik E, Reddy P S N, Ganesh K, Gandewar K, Singh K P, et al. Impact of school-based HIV and AIDS education for adolescents in Bombay, India. SE Asian J Trop Med Public Health 1997; 27: 692-5.

22.- Damiba A, Vermund S H, Kelley K F. Gonorrhea, syphilis, and trichomoniasis among prostitutes in Burkina Faso. E Afr Med J 1990; 67; 473-7.

23.- Islam M M, Karim E, Mian M A, Kristensen S, Chowdhury M R, Vermund S H. An update on the prevelance of HIV/AIDS in Bangladesh. SE Asian J Trop Med Public Health 1999: 30: 246-50.

24.- Pasha O, Fikree F F, Vermund S. Determinants of unmet need for family planning in squatter settlements in Karachi, Pakistan. Asia Pac Popul J 2001; 16: 93108.

25.- Oddo D, Acuña G. Opportunistic infections in Chilean autopsy cases, 1960-1986. Bull Pan Am Health Organ 1988; 22: 17-26.

Correspondencia a:

Sten Vermund

sten@uab.edu

Guillermo Acuña L.

gacuna@netline.cl 